\title{
Saint's Progeny: Assotto Saint, Gay Black Poets, and Poetic Agency in the Field of the Queer Symbolic
}

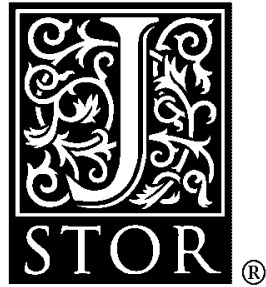

\author{
Douglas Steward
}

African American Review, Vol. 33, No. 3 (Autumn, 1999), 507-518.

Stable URL:

http://links.jstor.org/sici?sici=1062-4783\%28199923\%2933\%3A3\%3C507\%3ASPASGB\%3E2.0.CO\%3B2-T

African American Review is currently published by St. Louis University.

Your use of the JSTOR archive indicates your acceptance of JSTOR's Terms and Conditions of Use, available at http://www.jstor.org/about/terms.html. JSTOR's Terms and Conditions of Use provides, in part, that unless you have obtained prior permission, you may not download an entire issue of a journal or multiple copies of articles, and you may use content in the JSTOR archive only for your personal, non-commercial use.

Please contact the publisher regarding any further use of this work. Publisher contact information may be obtained at http://www.jstor.org/journals/slu.html.

Each copy of any part of a JSTOR transmission must contain the same copyright notice that appears on the screen or printed page of such transmission.

JSTOR is an independent not-for-profit organization dedicated to creating and preserving a digital archive of scholarly journals. For more information regarding JSTOR, please contact jstor-info@ umich.edu. 


\section{Saint's Progeny: Assotto Saint, Gay Black Poets, and Poetic Agency in the Field of the Queer Symbolic}

agency is the hiatus in iterability (Judith Butler, Bodies That Matter 220)

transformation is only real when you share it (Assotto Saint, "Sacred Life" 261)

$\mathrm{I}$ n "Why I Write," poet and playwright Assotto Saint notes that "most revolutions-be they political, social, spiritual, or economic-are usually complemented by one in literature" (3). Such literary revolutions should be considered complementary in a strong sense, not as colorful accessories that serve only as window-dressing for the more substantial rearrangement of forms of government and social relations, recastings of the ligature between human and divine, or revision of cash nexus and modes of production and distribution. Rather, literature as "a public process that reflects private passions" (4) acts as a primary locus for reworking social categories, for rearticulating the whole terrain of values and parties involved. Under traditional mimetic models, either map (literature) or territory ("real" economic or social practices) precedes the other. Vulgar Marxist criticism would view the map as at best a distorted representation of a preexisting territory or at worst as guiltily complicit in the perpetuation of that territory's unjust geography of oppression. On the other hand, aesthetes of the Wilde or Mallarmé variety would turn mimeticism on its head, privileging the artistic articulation as preexisting the "real." What Saint points us toward is the strong sense of complementary: literature as social force, without which revolution would remain incomplete, if not impossible. Under this model, map and territory are drawn and constructed simultaneously; the map is projected onto the territory, which only becomes visible as "the territory" as it stands in support of the phantasmatic projection of a particular social cartography.

The revolution in which Saint's works participate involves a reexamination of the place of the gay black male in U.S. society, and the complementary literary revolution began in earnest in the 1980s, especially with the publication in 1986 of Joseph Beam's anthology In the Life. ${ }^{1}$ Beam frankly announced his awareness that he and the other contributors were "making history" (16), and he understood his project as both archival and revolutionary. Underscoring the necessity of putting gay black writing into print and anticipating the well-known ACT UP equation "Silence = Death," Beam would argue that "transmitting our stories by word of mouth does not possess archival permanence. Survival is visibility" (15). In an often quoted slogan, Beam announced the social importance of his anthology's potential cultural work: "Black men loving Black men is the revolutionary act of the eighties"
Douglas Steward teaches and studies American literature and literary theory at the University of Kansas, where he is a doctoral candidate. His research currently centers on the ways in which literature articulates agency. 
(240). This is a publishing revolution that has continued into the '90s, and Assotto Saint has placed a specifically poetic stamp on it in the three anthologies he has edited or conceived: The Road Before Us (1991), Here to Dare (1992), and Milking Black Bull (1995). I would like to examine Saint's work as a poetic-editorial engagement with the social transformations currently occurring in gay black existence. While poetry's density naturally offers complex interpretive possibilities for the "didactic and political" socio-aesthetic intervention that Saint's work makes (Saint, "Why I Write" 7), this complexity is heightened by the fact that Saint did not limit his "poetic" work to producing poetry himself. In addition to the poetry he himself wrote, he was instrumental in the selection and publication of poetry by other writers. Saint's work with Other Countries (the New York gay black writer's collective) and as editor of the above anthologies dispersed his own agency among scores of writers, rendering an account of "his" poetic work problematic, since it must also consider his editorship.

At the same time, Saint's editorship offers the possibility of using him as a common denominator in discussing the work of the various authors in his anthologies. Viewing him as a unifying common denominator is a critical fiction that allows me to navigate more easily the complex issues involved in discussing the social agency of what is clearly a collective undertaking: Rather than taking each author or each poem separately, Saint's umbrella agency as editor allows me to treat the poems in his anthologies as, in some way, intentionally unified. Rather than reductively attributing all such agency to Saint himself, however, I suggest that Saint's editorial work consciously (but also necessarily) disperses the agency of social intervention among numerous voices. A collective, poetic project of this kind exploits some of the best (that is, most effectual and intellectually rigorous) postmodern strategies of social transformation. Under such strategies, the individual's ability to effect change of any sort is quite attenuated; against Modernist individualism, the intersubjectivity of all social relations is emphasized. Given the intersubjective character of social transformation as postmodern theory conceives it, collective projects such as anthologies are particularly important participants in refiguring symbolic relations, and a figurehead editor provides a convenient if fictive way of talking about the agency of this collective project. Moreover, the editorial selection inherent in the production of anthologies "frames" a certain voice for the work as a whole, unifying the collection. And yet, that voice nevertheless remains polyphonic and irreducible to a unitary discourse, giving the lie to a critical fiction such as the one I here offer, in which Assotto Saint is elevated to the puissant status of doyenne of gay black poetry. (See the later discussion of Saint as phallic mother.)

A wide range of race and queer theory today illuminates the difficulties facing political activism at a time when utopian, essentialist identity politics are, for many activists, both outdated and indispensable. For example, Lauren Berlant and Elizabeth Freeman note that "Queer Nation's nationaliststyle camp counterpolitics" engage with the complicated space of sexual hegemony, "shifting between a utopian politics of identity, difference, dispersion, and specificity and a pluralist agenda in the liberal sense that imagines a 'gorgeous mosaic' of difference without a model of conflict" (197). However, Berlant and Freeman caution that Queer Nation's "campaign has not yet ... left behind the fantasies of glamour and of homogeneity that characterize American nationalism itself." In its fixation on object-choice and essentialist identity politics, the group falls short of the "utopian promise" of a viable "queer symbolic" (215). In his influential article on the homophobia rampant in psychoanalytic discourse, "Homo-Narcissism; or Heterosexuality," 
Michael Warner rather simplistically rejects the Freudian and Lacanian traditions in order to enable precisely the kind of utopianism that Berlant and Freeman consider to be Queer Nation's shortcoming: "The homosexual who makes the choice of 'what he himself would like to be,' " argues Warner, "expresses the utopian erotics of modern subjectivity" (206). While Freeman and Berlant frankly confront the problematic aspects of Queer Nation's utopianism, Warner's gesture typifies an understandable frustration with "working through" knotty problems in contemporary discourse on sexuality rather than simply cutting them out.

I suggest nevertheless that such knots cannot profitably be excised whole. Rather, they must be worked through slowly, since too conveniently cutting through such knots leaves open the unsettling possibility of a violent return of the repressed. Critical discourse is of course by no means the only method of working through such nodes of social trauma. On the contrary, literature constantly engages with the most difficult aspects of social existence in order, in Fredric Jameson's Althusserian formulation, to provide imaginary resolutions to real problems. In the introduction to The Road Before Us, for example, Saint argues that his project is "a reconstitution" of an

America that acknowledges "fully participating gay black voices" (xxiv). As such an empowering reconstitution or rearticulation, Saint's poetry and editorial selection confront and work through traumatic knots that relate specifically to discourses on both sexual and racial minorities. This article merely begins to consider these discourses where they intersect most spectacularly: the phallus.

The black man's relationship to the phallus in the Western symbolic economy has long been a problematic one. As Frantz Fanon has noted in Peaux noires/Masques blancs, in Western discourse on black men's sexuality "le nègre est éclipsé. Il est fait membre. Il est pénis" ("The negro is eclipsed. He is made into a member. He is the penis.') (137). Moreover, as Gregory Woods observes, for gay writers "the sucked cock is paradoxically both a gag and a voice. As such it is the model for all gay utterance, the physical emblem of social requirement: the gay poet's opposed needs to be discreet and expressive" (189). Rather than rejecting psychoanalytic formulations out of hand because they are often inconveniently homophobic (such facile rejections, alas, rarely prove viable), I suggest that Jacques Lacan's tripartite analysis of the symbolic, imaginary, and real phallus ${ }^{2}$ provides a useful means of schematizing the place of the phallus in gay black men's poetry, since these poets are (1) racially reduced in synecdochic fashion to the real phallus by dominant discursive regimes, both gay and mainstream, (2) creatively enabled by the imaginary phallus in "the tradition of all phallusfetishistic literature by gay men" (Woods 189), and (3) gagged as masculine subjects by the symbolic phallus of the body politic's dominant discourses on sexuality. That psychoanalysis has been complicit in homophobic discourse does not mean that its categories do not bear on gay existence. On the contrary, in such critical formulations as Lacan's, phallocentrism and homophobia become mere denaturalized (albeit still traumatic) elements of dominant discourse. Recognition and analysis of such discursive regimes permit an intelligible but subverted repetition of their categories-a repetition with a difference that opens up the possibility of social transformation. Lacan's work in particular offers the possibility for such subversion thanks to its insistence on the linguistic character of the psyche and its inscription in cultural modes of power. ${ }^{3}$ 
The Real Phallus: Stereotype

$\mathrm{I}$ $\mathrm{n}$ its most basic form, this repetition with a difference will simply exaggerate or invert (pun intended) the typical formulation. To begin with the synecdochic reduction of the black male to the real phallus, Thom Bean's "A

Love Poem for White Boys Who Don't Know Who I Am" emphasizes even in its title the poverty of a discourse that objectifies individuals-even if this discourse takes the individual as a privileged objectchoice. Mocking the gay community's half-hearted gestures at integration, the poem's persona announces, "i am the trick you turn to / and never really love / $\mathrm{i}$ am desired at night / and never treated the same / in daylight" (10). Fully aware of his synecdochic reduction, the speaker exposes white gay hypocrisy in naming the terms of interracial sex: " $\mathrm{i}$ am the living dildo on which / you seek your comic and tragic relief / i am the chair upon which / you sit your frustrations / and base your superiority" (11). These lines are perhaps more subtle than they first appear. The word dildo, for instance, exaggerates the objectification inherent in reducing the black man to his cock. Moreover, in figuring the act of receptive anal sex as sitting on a chair, Bean deploys a counter-metonymy: The body of the speaker's sexual partner becomes an embodiment of his "frustrations" and "superiority." The speaker no longer has intercourse with another person, but with a set of emotions and racial attitudes, and the act of sex is a "relief" of the other's anxiety.

More extreme is the strategy of inverting the stereotypical notion of the black man's enormous cock-turning that fetish into a weapon against perpetrators of racist speech and violence. Sabah As-Sabah's hard-edged "Invocation" undertakes such an inversion in writing a racist skinhead into the role of passive (of course) and unwilling partner:

I want to fuck a skinhead
hard
ripping flesh
thrust all twelve inches of black
down his sewered hole...
I'm gonna pump history darker
with every stroke (8)

These lines emphasize the historicity of hate speech, the fact that the skinhead is only a representative figure of a pervasive kind of discourse that runs back 400 years. As Judith Butler remarks in her recent analysis of hate speech, Excitable Speech, "An 'act' is not a momentary happening, but a certain nexus of temporal horizons, the condensation of iterability that exceeds the moment it occasions" (14). It is this very "nexus of temporal horizons" or "condensed historicity" (Butler 3) that the speaker of "Invocation" both invokes and wishes to counter with "four hundred years of semen" (As-Sabah 8). In reiterating a stereotype that is susceptible to racist hystericization, the speaker perpetuates such stereotypes in order, paradoxically, to counter them. The speaker further plays on/off dominant phobias by writing a masculine, straight-identified male into the role of unwilling, "passive" partner. Although the subtlety of Thom Bean's "Love Poem" might provoke thought on the part of a reader who does not already sympathize with gay black men's concerns, the exaggerated violence of Sabah As-Sabah's poem would likely provoke only more anger. Of course, this raises the question of what readership Saint's anthologies target. In a poem titled "The Geography of Poetry," Saint makes clear that he has no illusions about the marketing of gay black literature. After mentioning several poets whose work is displayed in prominent places at a Barnes \& Noble store, the poem's speaker apostrophizes: 
stacked amongst langston, nikki, \& countee

maya who looked mad

the blues had her bad

zake tell me did you demand to be segregated

'does color modify poetry'

$i$ asked the manager

he patted me on my head whispered

'it's always been this way' (27-28)

Indeed, gay black literature is even more likely to be found in the "gay \& lesbian" section of major bookstores than in the African-American section. The gay/lesbian shelf is, arguably, an even more "ghettoized" section, since several (although not many) AfricanAmerican writers have been well assimilated into mainstream literature, while no openly self-identified lesbian or gay literature has been.

In his keynote address to "Subterfuge: Queer Writers/Activists in the Bible Belt," Karl Woelz has argued that this ghettoization is yet another ambivalent element of dominant structures to which gay writers should give a positive turn. Woelz remarks that "straight people don't read lesbian and gay fiction" and questions, "therefore, why should queer writers tailor their work for an audience which doesn't exist?" He asserts that,

\begin{abstract}
as a writer of gay fiction, it is not my responsibility to play tour guide to a straight audience; to explain what a "popper" or a "trick" is; to clarify that the phrase "Oh, Mary, please!" is not a prayer offered to the Virgin Mother. My responsibility, as I see it, is to render, as fully and truthfully as possible, the reality of whatever gay experience I'm examining so that it provides other queers with that shock of recognition that only honestly drawn fiction can produce-provides them with new ways to see and hear the world.
\end{abstract}

Woelz's remarks point to the important intracommunal work that gay (and in the present context, black male) literature performs. Although Saint's own poem "The Geography of Poetry" voices anxiety about literary ghettos, his anthologies are clearly marketed toward the ghetto audience that the publishers are doubtless aware will be their virtually exclusive audience, and the repetition of phallus stereotypes clearly assumes a male audience.

At the same time, the assumed audience of the poetry underscores the fact that the repetition of stereotypes in work by gay black men is not merely a reproduction of dominant, racist discourse. Rather, as Homi Bhabha argues, "the point of intervention ... shift[s] from the ready recognition of images as positive or negative, to an understanding of the processes of subjectification made possible (and plausible) through stereotypical discourse" (67). When a poet "cites" a stereotype, he makes his discourse readily legible. Despite the trauma inherent in "negative" stereotypes, these stereotypes are also "positive" insofar as they function in a cultural, semiotic system: They signify and make recognizable.

Stereotyped discourse is one of the ways in which individuals belonging to minorities are interpellated into the social text and, indeed, come to understand themselves as belonging to those minorities. Stereotypes such as the black man's bestial libido and his enormous cock "hail" subjects that are susceptible, based on certain race characteristics, to this particular form of address from the Other. ${ }^{4}$ As-Sabah's poem explicitly invokes this interpellatory aspect of racialized speech:

CALL MY NAME
"Nigger"
CALL MY NAME
"Jigaboo"
CALL MY NAME
"Colored"
CALL MY NAME
"Black"
CALL MY NAME
"African" (9)

As Butler states, "One comes to 'exist' by virtue of [a] fundamental dependency on the address of the Other. One 'exists' not only by virtue of being recognized, but, in a prior sense, by being recognizable" (Excitable 5). The repetition of such stereotypes thus makes gay black subjectivity recognizable, 
but, as Woelz remarks, in its repetition with a difference gay literature provides its readers "with new ways to see and hear the world." The subversion of stereotypes necessarily deploys these stereotypes, for "to judge the stereotyped image on the basis of a prior political normativity is to dismiss it, not to displace it, which is only possible by engaging with its effectivity" (Bhabha 67).

\section{The Imaginary Phallus: Identification}

itational strategies in poetry are not, of course, limited to stereotyped discourse. On the contrary, cited stereotypes such as the black man's reduction to the real phallus are rendered especially ambivalent-that is, vulnerable to antiracist, antihomophobic subversion-through the empowering citation of poetic precedents for gay black men. In fact, Saint's

"Geography of Poetry" employs this strategy: At the same time that it questions the ghettoization of black poets' work, the poem cites the names of several of what Saint views as predecessor poets. In other words, the poem's speaker identifies with the cited authors, thereby authorizing himself to write. This sort of citation of poetic precedent is far from new: Invocations of past writers have long served as a method of positioning oneself in the poetic field. What seems new in the kind of poetry that Saint anthologizes is a focus on very recent poetic paternity. ${ }^{5}$ The brevity of this tradition derives perhaps from some of the same societal circumstances that lead Ron Silliman to observe that "there is something about American poetry in the 20th century which is generating an increasingly rapid evolution of form(s)" (661). At least, we can understand this brevity as an example of Silliman's observation if we understand "form(s)" as "social form" and include as a part of that form the way in which the poetry is framed by publication strategies. At the most, this brief tradition extends back to the Harlem Renaissance, which Alden Reimonenq has identified as the "first Black gay Renaissance" (qtd. in Emmanuel Nelson 17). But more frequently, both the poets themselves and the anthologies emphasize the much more current moment of the ' 80 s and '90s, citing as predecessors writers who have immediately preceded or in fact been contemporaries of the poets in question. Insofar as this strategy relies on the specificity of gay black experience, this invocation is an instance of what Woods calls a reliance on "the tradition of all phallus-fetishistic literature by gay men" - a reliance that Woods believes acts to empower the gay voice (189).

Such a gay phallus-cum-muse is primarily a phantasmatic node that enables community subjectification. To cite another of Butler's excellent formulations, "Identifications belong to the imaginary; they are phantasmatic efforts of alignment, loyalty, ambiguous and cross-corporeal cohabitations; they unsettle the ' $\mathrm{I}$ '; they are the sedi-

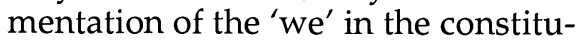
tion of any 'I,' the structuring presence of alterity in the very formulation of the ' $\mathrm{I}$ ' " (Bodies 105). We can thus consider this identificatory fetish-phallus as a privileged topos in the elaboration of a community identity that uses it to establish loyalties and a common "we" that supports, authorizes, and positions the "I." However, when we also consider it as an imaginary phallus in the Lacanian sense, then the strange cover illustration of Milking Black Bull suddenly, eerily makes sense. The back cover declares that, in this collection, the "next wave has arrived. Eleven gay black poets continue the work of Melvin Dixon, Essex Hemphill and Assotto Saint, exploring the diversity of gay black life in our time." On the title-page, we read that the anthology was "conceived" by Assotto Saint (who in fact died prior to its publication). The anthology thus writes Saint into a 
maternal role for the eleven poets represented.

The cover illustration makes surprisingly literal the dual possibility of a "phallic mother" and a gay fetish-phallus that enables gay voices. A hunky black man in birth posture reclines on an American flag while reaching up to clutch the penis and one horn of an astrological bull. The man's penis stretches out into a long umbilical cord, to which a child in the fetal position is still attached. "Milk" from the stellar bull presumably transmutes through the man's body into that of the child, nourishing it with astral sustenance. In "The Labyrinth," Brad Johnson's poem from which the anthology's title derives, the speaker indeed has sex with a hypermasculine, Minotaur-like "Bull." The poem ends with the speaker, in a sense, nursing:

\section{impaled on the cock at the crotch of sex and viscous semen}

(on down to long bullcock with glans swelling, succulent plum, smooth balls)

in his navel, my tongue on Bull's milk (64)

The anthology's cover illustration metaphorizes this sexual relation into a poetic one, in which the trinity DixonHemphill-Saint serves as a phallicmother figure that offers nourishing semen-milk to its children. That this takes place on top of an American flag only serves to emphasize the minority community's relationship to the greater social text, the production of its discourse in the field of national discourses.

Appropriately enough, Essex Hemphill's own "Rights and Permissions," included in Saint's earlier anthology The Road Before Us, also uses the image of mouth and semen that Johnson's "Labyrinth" invokes, but the speaker puts his own semen, not that of someone else, to his mouth. The poem turns on an evocation of the mystery involved in ejecting "seed." After having held his own semen, for instance, the speaker's hands "return / to their tasks / as if nothing / out of place / has occurred," and the speaker "go[es] on being" (67). After cataloguing some of the indignities of aging, the speaker concludes the poem:

"Sometimes I hold / my warm seed / up to my mouth / and kiss it" (68).

This act of tenderness seems in part autoerotic: After all, the speaker kisses his own semen. In the present context, such onanism would seem to indicate Hemphill's lack of a poetic precedent on which to feed, suggesting that the poet was forced to fall back on his own seminal resources, lacking the kind of imaginary identifications - the "phantasmatic efforts of alignment, loyalty, ambiguous and cross-corporeal cohabitations" (Butler, Bodies 105)—that nourish the poets of Milking Black Bull's "next wave."

At the same time, though, the poem's emphasis on aging and on what the speaker "learn[s] / as age advances" points to Hemphill's role as an older model for younger writers and to his ability to communicate experience through poetry. In this respect, "Rights and Permissions" underscores Hemphill's potential to fulfill a paternal function. Under such a reading, one would want to insist on the word choice seed over semen, or any of the various slang possibilities, since it lends gravity to the situation and suggests the reproductive faculty of the substance more than any of the others do. "Warm," of course, further emphasizes this faculty. One would also want to insist on the difference in tone between the poem's beginning and end. Whereas at the beginning the speaker whispers "I'm sorry" to his semen before turning it into the toilet, at the end of the poem he kisses it. Although both the beginning and concluding stanzas open with the word sometimes, reading through the speaker's ruminations on aging gives the sense that something has been learned over the course of the poem-in short, that the poem has a trajectory, and that the end is decidedly more positive than 
the beginning. The poem's final kiss is thus an autopollination. Milking Black $B$ ull retroactively affirms the paternity that is in Hemphill's poem only potential.

\section{The Symbolic Phallus: Iteration}

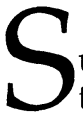
uch issues of paternity and phantasmatic identification ultimately lead to a consideration of the symbolic phallus in these anthologies, for the symbolic is, in Lacan, an abstraction of language itself-the big Other that both delimits and empowers subjectivity. As Lacan writes,

\begin{abstract}
La Loi primordiale est donc celle qui en réglant l'alliance superpose le règne de la culture au règne de la nature livré à la loi de l'accouplement .... Cette loi se fait donc suffisament connaître comme identique à un ordre de langage. ('The primordial Law is that which, in regulating the alliance, superposes the reign of culture onto that of a nature given over to the law of coupling .... This law thus sufficiently makes itself known as identical with an order of language.') ("Fonction" 277)
\end{abstract}

As a system of possibilities and impossibilities, injunctions and prohibitions, thinkables and unthinkables, the symbolic is regulated by what Lacan calls the law of the father. Lacan's theory here merges with culturally dominant gender-power structures and biological sex such that the symbolic phallus is "le signifiant privilégié de cette marque où la part du logos se conjoint à l'avènement du désir" ('the privileged signifier of that mark whereby the role of the logos is joined to the advent of desire') ("Signification" 692). In other words, the symbolic phallus represents the law of the father insofar as "la vraie fonction $d u$ Père ... est d'unir (et non pas d'opposer) un désir à la Loi" ('the true function of the Father .... is to unite [and not to oppose] a desire to the Law') ("Subversion" 824). The price of not uniting desire and law is, of course, psychosis, which has led some commentators on Lacan to conclude that his entire work is an obscurantist blueprint for phallogocentric fascism, since on a first reading Lacan seems to imply that the unison must occur between individual desire and a law that is fully consonant with dominant modes of structuring and directing that desire.

The potential in Lacan's work that Saint's anthologies point us toward, though, is the performance or the enactment of self. If on the one hand this enactment must take place within certain parameters largely determined by preexisting discourses that have deeply embedded racist and homophobic elements, the iteration of such discourses nevertheless entails a certain hiatus that leaves open the possibility of agentive intervention and the subversion of such discourse. Because discourse is itself intersubjective, such intervention must also be a group effort, as Adrienne Rich implies in "Hunger," a poem dedicated to Audre Lorde: "The passion to be inscribed her body. / Until we find each other, we are alone" (14). Saint echoes this sentiment in asserting that "transformation is only real when you share it"

("Sacred Life" 261). In gay male literature specifically, the phallus is a primary site of discursive ambivalence since (1) in the culture at large its veiled manifestation oversees the reproduction of social structures that benefit men over women. At the same time, (2) the phallus serves an obvious emblematic function for the gay male community, such that Lacan's view of the phallus as "the privileged signifier" of the conjunction of subjectivity and desire ("Signification" 692) slides more or less directly into Woods's understanding of it as "the model for all gay utterance, the physical emblem of social requirement" (189). (Obviously, this is not an identificatory node in lesbian literature, suggesting a significant difference in the ways gay men and women are able to inscribe themselves into larger discourses.) 
There is thus in the poetry under question an emphasis on the active, communal production of gay black subjectivity and the symbols necessary for its enactment - "the dream of a common language," in Rich's words (7). Redvers JeanMarie's "Hejira," for instance, gives The Road Before Us its title in a passage that underscores the lack of and need for a language that speaks gay black existence: "A sense of plenitude / The road before us with no symbols / A restrictive sense of nothingness / Wrapped us firm." Clearly, JeanMarie refers to a kind of symbolic castration that silences and binds. However, the poem is positive in its sense of possibility: "I've a natural strength," the speaker declares, "And can follow you." The you here should probably be understood as Saint himself, since the poem is dedicated to his "real" name, Yves Lubin. Despite the speaker's avowal that "What we've become / Has no name" (79), the anthologies in which "Hejira" appears (both The Road Before Us and Milking Black Bull) are efforts at naming that inexpressible existence.

On the one hand, then, a speaker such as that of Alan Miller's "Everywhere There's Evidence" announces the gagging phallus when he ponders on his "heart, dangerous / as a bone in [his] throat" (99). But, on the other hand, poets such as John D. Williams explicitly examine the ramifications of forging a new symbology from pieces of the old, avoiding symbolic castration or gagging through a performative conception of identity. In "AIDS:

Considerations of Fear," Williams presents this performative identity as a tentative one, always troubled by the specter of AIDS. Indeed, in this time of sexual crisis and disease panic, one's own identity and ability to speak are undercut by the anonymity of one's sexual partners: The speaker avers, "because i do not want to tell you / about the many men i did not know / who touched me, / when you ask me if i am afraid, / my mouth stutters into silence- / i do not even know who they were." It is as though the other of desire, being nameless, fails to hail the speaker effectively. Nevertheless, the speaker finds that the meaning of his identity has been molded by the hands that were not afraid of his body, for, he says,

$$
\begin{aligned}
& \text { i, my feelings / my person } \\
& \text { and my entire self were shaped } \\
& \text { against/within } \\
& \text { the meanings of those hands. }
\end{aligned}
$$

These remarkable lines underscore the instability of "identity" in slipping from the unitary " $\mathrm{i}$ " to the ambiguous plurality of affectivity and back to the illusory unity of a "person" and in displacing the agency of identity production with the slashed prepositions "against/within": Is it the speaker himself who shapes his identity against others' hands, or is his identity shaped within those hands? The poem's final lines point to the fact that identity is but a retroactive effect:

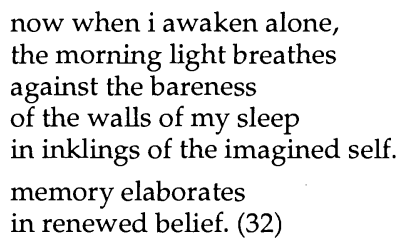

While "AIDS: Considerations of Fear" explores the tentative nature of identity and its retroactive production in memory, Williams's "Billie Holiday: Billie in the Music" and "October Letter" look at the self as performative. In both poems this performance is an uncertain one compared to melody, the "meaning" that arranged sounds create. The speaker of "Billie Holiday" confidently asserts that "the meaning is melody / and i can tell you about melody," even though he describes the melody of self as "shiftings" and "scattering":

... i am returned to myself ...

in the shiftings of my voice

and limbs

$i$ enact myself,

scattering these sounds

from my mouth

like milkweed

in an afternoon light. (35) 
If, then, the self is "rediscovered," suggesting that it was always there to be found, it is nevertheless an ephemeral kind of melody or meaning that dissipates in the very process of enactment. "October Letter" presents much the same view of selfhood, but does so in the context of a "we." The poems both emphasize the melancholia of autumn, closely associating it with nostalgic memory, and "October Letter" asserts that the "disilluminating grief" of autumn "is not the center of things- / everywhere we reappear to one another / in electrified distortion" (42).

Finally, the poem offers no other "center" in place of grief but ends affirming the necessarily aleatory character of self-understanding in such a context of intersubjective "distortion": "one binds upon oneself," the speaker concludes, "as if one were understood" (43; my emphasis). Although these poems are not explicitly about the production of identity through poetry, I suggest that they in fact offer analyses of the way in which gay black poets do go about producing a sense of identity from within the system of the dominant symbolic.

How, then, are we to understand the mechanism of communal subjectification that Saint's anthologies undertake? Cary Nelson perceptively notes of poetry's ability to perform a specific kind of cultural work that, "in part because of its long historical links with song and with the speaking voice, and in part because we are especially aware of its formal properties, poetry offers us subject positions we can take up consciously and with a paradoxically self-conscious sense of personal identification" (124). Nelson is certainly right to point out poetry's position as a privileged crossroads of the linguistic and the personal. However, his formulation is perhaps too voluntaristic, suggesting that poetry magically offers up positions that are easily adopted, or not, just as the subject pleases. As I have attempted to show, subject-positions in black gay poetry are overdetermined by preexisting structures of the symbolic; the elaboration of divergent subject positions must and do work from/within dominant discourses, even if they are traumatic and racist ones such as the synecdochic reduction of the black male to his putatively enormous cock. However, such a stereotype contains the seed, as it were, of its own destruction, for the phallus-as the sublime object of gay male ideology, its objet petit a- "emerges to solve the deadlock of how the subject is to find support in the big Other (the symbolic order)" (Žižek, Metastases 178). Gay black representations of the phallus subvert recognizable images of the gay/black phallus, and they draw on a tradition, however brief, of writers who have also possessed and spoken from the gay/black phallus. In thus circumventing symbolic castration,

Saint's progeny effectively engage in a tentative yet decidedly agentive elaboration of gay black identity in the field of what we can begin to call the queer symbolic.

Notes 1. See Essex Hemphill's Introduction to Brother to Brother, an anthology conceived by Beam, for more information on the explosion of journals and other venues for gay black writing in the '80s.

2. There is no one text to which we can turn for a full and coherent elaboration of Lacan's own thoughts on the phallus. However, in his excellent Introductory Dictionary of Lacanian Psychoanalysis, Dylan Evans references numerous relevant passages and provides his own account of Lacan's conception of the phallus's functions. The real phallus is the unstable term in which the phallus-as-symbolic-function and the biological penis intersect: The term real phallus thus carries a certain amount of connotative baggage that the penis does not necessarily carry. It is of the imaginary phallus that Lacan thinks in writing that "l'enfant appréhende dès l'origine que la mère 'contient' le phallus" ('the child understands from the beginning that the mother "contains" the phallus') ("Signification" 693). Lacan understands the imaginary phallus as woman's most desired object, her objet petit a, such 
that "C'est pour ce qu'elle n'est pas qu'elle entend être désirée en même temps qu'aimée" ('It is for what she is not that she believes herself desired and at the same time loved') (694). The imaginary phallus is thus a fetish (694). I address the function of the symbolic phallus below.

3. Although this is not the place for a review of the voluminous literature on Lacan, a word on his appropriateness is perhaps in order. Simply put, Lacan's detractors argue that his reading of Freud does nothing to improve on his predecessor's sexism. Far from it, they argue, Lacan's insistence on the phallus and his ominous, putatively deterministic theory of the Law of the Father aggravate Freud beyond redemption at the same time that the incomprehensible density of his inhuman prose carries out on the undeserving reader one of the many sadistic operations he theorizes: symbolic castration. As Judith Butler puts it, "There does seem to be a romanticization or, indeed, a religious idealization of 'failure,' humility and limitation before the Law, which makes the Lacanian narrative suspect" (Gender Trouble 56). However, once we have understood Lacan's work as a kind of slave morality (57) and absorbed his understanding of gender as fiction, then his work becomes quite useful as a sophisticated methodology for analyzing narratives. It does not, of course, pronounce timeless truths about men and women. In the present context, for instance, my use of Lacan will show how stereotypes of the "real" black phallus rest on a fantasy-quite supplemental to reality-about its size and virility. That these fantasies are supplemental does not reduce their effectivity.

For the most provocative, productive revision of Lacan to date and an investigation of his usefulness in lesbian studies, see Judith Butler's impeccable Bodies That Matter: On the Discursive Limits of "Sex". For a defense of Lacan's importance in political theory at large, see Slavoj Žižek's magisterial study The Sublime Object of Ideology.

4. This is not a procedure unique to gay writing, as readers of Richard Wright's Native Son know. Bigger Thomas reacts throughout the novel in ways that he thinks he must act, given stereotypical notions about black men. Rather than reject stereotypes out of hand, Wright recognized the artist's imagination as "a kind of community medium of exchange" and resisted the "mental censor" that told him not to write the book $(853,867)$. In other words, he chose to work through the messy problems Bigger represents rather than sweep them under a mental carpet.

5. Naturally, allusions of a more traditional nature also contribute to the citational authorization of the poetry in Saint's anthologies. To present but one example, Michael Wiggins's excellent "Mosaic Children" invokes Walt Whitman in the line "sing the little boy electric blues" (140), a modification of "I sing the body electric." Such a citation exploits its iterative hiatus in order to insert into the citation a potentially "gay" element- "little boy"—as well as a "black" element—"the blues." The shift from Whitman's first-person "l" to the second person points to the more openly intersubjective character of the poetry in Saint's anthologies.

As-Sabah, Sabah. "Invocation." Saint, Road 8-9.

Beam, Joseph, ed. In the Life: A Gay Black Anthology. Boston: Alyson, 1986.

Bean, Thom. "A Love Poem for White Boys Who Don't Know Who I Am." Saint, Road 10-15.

Berlant, Lauren, and Elizabeth Freeman. "Queer Nationality." Warner, Fear 193-229.

Bhabha, Homi. The Location of Culture. London: Routledge, 1994.

Butler, Judith. Bodies That Matter: On the Discursive Limits of "Sex". New York: Routledge, 1993.

-. Excitable Speech: A Politics of the Performative. New York: Routledge, 1997.

-. Gender Trouble: Feminism and the Subversion of Identity. New York: Routledge, 1990.

Evans, Thomas. An Introductory Dictionary of Lacanian Psychoanalysis. London: Routledge, 1996.

Fanon, Frantz. Peaux noires/Masques blancs. Paris: Seuil, 1952.

Hemphill, Essex. "Rights and Permissions." Saint, Road 67-68.

JeanMarie, Redvers. "Hejira." Saint, Road 79.

Johnson, Brad. "The Labyrinth." Saint, Milking 64.

Lacan, Jacques. "Fonction et champ de la parole et du langage en psychanalyse." Écrits. Paris:

Seuil, 1966. 237-322.

—. "La Signification du Phallus." Écrits. Paris: Seuil, 1966. 685-95.

-. "Subversion du sujet et dialectique du désir." Écrits. Paris: Seuil, 1966. 793-827.

Miller, Alan E. "Everywhere There's Evidence." Saint, Road 99-100.

Nelson, Cary. Repression and Recovery: Modern American Poetry and the Politics of Cultural

Memory, 1910-1945. Madison: U of Wisconsin P, 1989.

Nelson, Emmanuel S. "Towards a Transgressive Aesthetic: Gay Readings of Black Writing." James

White Review 11.3 (1994): 17.

Rich, Adrienne. The Dream of a Common Language. New York: Norton, 1978. 
Saint, Assotto. "The Geography of Poetry." Spells 27-28.

-, ed. Here to Dare: 10 Gay Black Poets. New York: Galiens, 1992.

—, ed. Milking Black Bull: 11 Gay Black Poets. Sicklerville, NJ: Vega, 1995.

—, ed. The Road Before Us: 100 Gay Black Poets. New York: Galiens, 1991.

-. "Sacred Life." Spells 255-71.

-. Spells of a Voodoo Doll: The Poems, Fiction, Essays and Plays of Assotto Saint. New York:

Richard Kasak, 1996.

-. "Why I Write." Spells 3-8.

Silliman, Ron. "Of Theory, To Practice." Postmodern American Poetry. Ed. Paul Hoover. New York: Norton, 1994. 660-63.

Warner, Michael, ed. Fear of a Queer Planet: Queer Social Politics and Social Theory. Cultural Politics 6. Minneapolis: U of Minnesota P, 1993.

—. "Homo-Narcissism; or, Heterosexuality." Engendering Men: The Question of Male Feminist Criticism. New York: Routledge, 1990. 190-206.

Wiggins, Michael. "Mosaic Children." Saint, Road 140-41.

Williams, John D. "AIDS: Considerations of Fear." Saint, Here 32.

-. "Billie Holliday: Billie in the Music." Saint, Here 35-36.

-. "October Letter." Saint, Here 42-43.

Woelz, Karl. "Promiscuity Saved My Life: The Politics of Writing and Reading Queerly." Subterfuge: Queer Writers/Activists in the Bible Belt. 11 Oct. 1996. Lawrence, KS.

Woods, Gregory. “'Absurd! Ridiculous! Disgusting!': Paradox in Poetry by Gay Men.” Lesbian and Gay Writing: An Anthology of Critical Essays. Ed. Mark Lilly. Philadelphia: Temple UP, 1990. 17598.

Wright, Richard. “How 'Bigger' Was Born.” Early Works: Lawd Today!, Uncle Tom's Children, Native Son. New York: Library of America, 1991. 853-81.

Žižek, Slavoj. The Metastases of Enjoyment: Six Essays on Woman and Causality. London: Verso, 1994.

-. The Sublime Object of Ideology. London: Verso, 1989.

\section{POSITION OPENING \\ English Department University of Virginia}

The English Department at the University of Virginia invites applications for an assistant professor in African American literature and cultural studies; we also welcome applications from more senior candidates. Employment will begin August 2000. Ph.D. or equivalent required. The area of specialization is open, but candidates concentrating in poetry and/or film studies are especially encouraged to apply. A letter of application, curriculum vitae, dossier of recommendations, and a writing sample of no more than 25 pages should be sent to Gordon Braden, Chair, Department of English, 219 Bryan Hall, P.O. Box 400121, Charlottesville, VA 22904-4121. Applications must be postmarked by 20 October 1999. The University of Virginia is an Equal Opportunity/Affirmative Action Employer. 